\title{
Tomato mottle mosaic virus intercepted by Australian biosecurity in Capsicum annuum seed
}

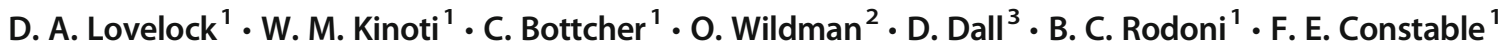

Received: 12 December 2019 / Accepted: 4 February 2020 / Published online: 7 February 2020

(C) Australasian Plant Pathology Society Inc. 2020

\begin{abstract}
The Tobamovirus, Tomato mottle mosaic virus (ToMMV), was first reported in Mexico in 2013. The virus is thought to pose a serious risk to capsicum (Capsicum annuum) and tomato (Solanum lycopersicum) crops as it is may break resistance. In May 2019 a shipment of imported capsicum seeds was submitted for testing on-shore and using a one-step RT-PCR which detects Solanaceous tobamoviruses, an amplicon of 811 base pairs (bp) was detected and direct sequencing of this amplicon indicated that it had 98\% - 99\% nucleotide (nt) identity to the same region in ToMMV isolates. A cDNA library was generated using the Illumina TruSeq Stranded Total RNA and sequenced using Illumina HiSeq 3000 technology, bioinformatic analysis confirmed the arrangement of a $6398 \mathrm{nt}$ genome which was $98 \%$ - 99\% nt identity with the type strain of ToMMV. This is the first report of ToMMV in Capsicum annuum seed.
\end{abstract}

Keywords Tobamovirus $\cdot$ Solanaceous $\cdot$ High throughput sequencing

Tomato mottle mosaic virus (ToMMV), a Tobamovirus species closely related to Tomato mosaic virus (ToMV), Tobacco mosaic virus (TMV) and the newly identified Tomato brown rugose fruit virus (ToBRFV), was first reported in Mexico in 2013 ( $\mathrm{Li}$ et al. 2013). The virus has now been detected in China, USA, Spain and Israel (Webster et al. 2014; Li et al. 2014; Turina et al. 2016; Ambrós et al. 2017; Luria et al. 2017; Che et al. 2018). The spread of the virus to new regions is potentially through seed, like other tobamoviruses. The virus is thought to pose a serious risk to capsicum (Capsicum annuum) and tomato (Solanum lycopersicum) crops as it may break resistance used to control other tobamoviruses, similarly to ToBRFV (Nagai et al. 2019). Since April 2019, all capsicum and tomato seeds imported to Australia have been tested for ToBRFV as a part of regulations imposed by the Australian government Department of Agriculture. In

D. A. Lovelock

david.lovelock@agriculture.vic.gov.au

1 Department of Jobs Precincts and Regions, Agribio, La Trobe University, 5 Ring Road, Bundoora, Victoria 3083, Australia

2 NSW Department of Primary Industries, Biosecurity and Food Safety, EMAI, Woodbridge Road, Menangle, NSW 2568, Australia

3 Australian Government Department of Agriculture, 18 Marcus Clarke St, Canberra, ACT 2601, Australia
May 2019 an imported shipment of approximately 6000 capsicum seeds was submitted for testing on-shore. RNA from a total of 15 sub-samples ( 400 seed per sample) was extracted as per the Australian method for solanaceous seed (Chambers et al. 2013) and tested using a one-step RT-PCR (Invitrogen) with the primer pair F-5476 and R-6287, which amplify part of the movement protein gene and all of the coat protein gene of Solanaceous Tobamovirus species (Levitzky et al. 2019). The PCR products were analysed on a $2 \%$ agarose gel (Invitrogen) and of the 15 sub-samples, nine produced an amplicon of 811 base pairs (bp) and direct sanger sequencing (Micromon, Monash University) of these amplicons indicated a $98 \%$ - 99\% nucleotide (nt) identity to the same region in ToMMV isolates and less than $90 \%$ nt identity to ToBRFV, ToMV and TMV isolates. A cDNA library was generated using the Illumina TruSeq Stranded Total RNA and sequenced using Illumina HiSeq 3000 technology. The reads were assembled and mapped to the original ToMMV isolate from Mexico (KF477193) using Geneious Prime® v2019.1.1. The genome coverage of the capsicum seed ToMMV isolate was $94 \%$ and it had $98 \%$ nucleotide (nt) identity to the Mexican ToMMV isolate (KF477193). Overlapping primers were designed and the resulting sequences confirmed the arrangement of the $6398 \mathrm{nt}$ genome (MN654021) generated by high throughput sequencing and bioinformatics analysis. The virus genome sequenced from the capsicum seed had $98 \%$ 99\% nt identity with other ToMMV isolates deposited onto 
GenBank and $85 \%$ nt identity to the ToMV (AF332868.1) and TMV (V01408.1) type species. The contaminated capsicum seed were destroyed or re-exported following Australian regulations. This is the first report of ToMMV in Capsicum annuиm seed and follows on from the detection in tomato seed in Israel (Turina et al. 2016), highlighting that ToMMV is likely seed borne and is a risk of introduction through contaminated seed into regions where it has not been previously found.

Acknowledgements This work was financially supported by the Australian Government Department of Agriculture.

\section{References}

Ambrós S, Martínez F, Ivars P, de la Iglesia F, Hernández C, Elena SF (2017) Molecular and biological characterization of an isolate of Tomato mottle mosaic virus (ToMMV) infecting tomato and other experimental hosts in a greenhouse in Valencia, Spain. Eur J Plant Pathol 149:261-268

Chambers GA, Seyb AM, Mackie J, Constable FE, Rodoni BC, Letham D, Davis K, Gibbs MJ (2013) First report of Pepper chat fruit viroid in traded tomato seed, an interception by Australian biosecurity. Plant Disease 97(10):1386
Che HY, Luo DQ, Cao XR (2018) First report of Tomato Mottle Mosaic Virus in tomato crops in China. Plant Disease 102(10):2051

Levitzky N, Smith E, Lachman O, Luria N, Mizrahi Y, Bakelman H, Sela N, Orly L, Milrot E, Dombrovsky A (2019) The bumblebee Bombus terrestris carries a primary inoculum of Tomato brown rugose fruit virus contributing to disease spread in tomatoes. PLoS One 14(1): e0210871. https://doi.org/10.1371/journal.pone.0210871

Li R, Gao S, Ling K-S (2013) Complete genome sequence of a new Tobamovirus naturally infecting tomatoes in Mexico. Genome Announcements 1(5):e00794-e00713. https://doi.org/10.1128/ genomeA.00794-13

Li YY, Wang CL, Xiang D, Li RH, Liu Y, Li F (2014) First report of Tomato mottle mosaic virus infection of pepper in China. Plant Dis 98:1447. https://doi.org/10.1094/PDIS-03-14-0317-PDN

Luria N, Smith E, Reingold V, Bekelman I, Lapidot M, Levin I, Elad N, Tam Y, Sela N, Abu-Ras A, Ezra N, Haberman A, Yitzhak L, Lachman O, Dombrovsky A (2017) A new israeli Tobamovirus isolate infects tomato plants harboring $\mathrm{Tm}-2^{2}$ resistance genes. PLoS One 12. https://doi.org/10.1371/journal.pone.0170429

Nagai A, Duarte LML, Chaves ALR, Peres LEP, dos Santos YAC (2019) Tomato mottle mosaic virus in Brazil and its relationship with Tm$2^{2}$ gene. Eur J Plant Pathol 155:353-359. https://doi.org/10.1007/ s10658-019-01762-7

Turina M, Geraats B, Ciuffo M (2016) First report of Tomato mottle mosaic virus in tomato crops in Israel. New Dis Rep 33(1)

Webster CG, Rosskopf EN, Lucas L, Mellinger HC, Adkins S (2014) First report of Tomato mottle mosaic virus infecting tomato in the United States. Plant Health Prog 15:151-152. https://doi.org/10. 1094/PHP-BR-14-0023 